\title{
Phosphoinositide 3-Kinase Cascade Facilitates $\mu$-Opioid Desensitization in Sensory Neurons by Altering G-Protein-Effector Interactions
}

\author{
Miao Tan, ${ }^{1}$ Matthias Groszer, ${ }^{2,3}$ Aiko M. Tan, ${ }^{1}$ Amy Pandya, ${ }^{2}$ Xin Liu, ${ }^{3}$ and Cui-Wei Xie ${ }^{1}$ \\ ${ }^{1}$ Department of Psychiatry and Biobehavioral Sciences, Neuropsychiatric Institute, University of California, Los Angeles (UCLA), Los Angeles, California \\ 90024-1759, ${ }^{2}$ Howard Hughes Medical Institute and Department of Molecular and Medical Pharmacology, and ${ }^{3}$ Department of Pathology and Laboratory \\ Medicine, UCLA School of Medicine, Los Angeles, California 90095-1735
}

Signaling via G-protein-coupled receptors undergoes desensitization after prolonged agonist exposure. Here we investigated the role of phosphoinositide 3-kinase (PI3K) and its downstream pathways in desensitization of $\mu$-opioid inhibition of neuronal Ca ${ }^{2+}$ channels. In cultured mouse dorsal root ganglion neurons, two mechanistically different forms of desensitization were observed after acute or chronic treatment with the $\mu$ agonist $\left[\mathrm{D}-\mathrm{Ala}^{2}, \mathrm{~N}-\mathrm{MePhe}^{4}, \mathrm{Gly}-\mathrm{ol}^{5}\right.$ ]-enkephalin (DAMG0). Chronic DAMGO desensitization was heterologous in nature and significantly attenuated by blocking the activity of PI3K or mitogen-activated protein kinase (MAPK). A combined application of PI3K and MAPK inhibitors showed no additive effect, suggesting that these two kinases act in a common pathway to facilitate chronic desensitization. Acute DAMG0 desensitization, however, was not affected by the inhibitors. Furthermore, upregulation of the PI3K-Akt pathway in mutant mice lacking phosphatase and tensin homolog, a lipid phosphatase counteracting PI3K, selectively enhanced chronic desensitization in a PI3K- and MAPK-dependent manner. Using the prepulse facilitation (PPF) test, we further examined changes in the voltage-dependent component of DAMGO action that requires direct interactions between $\beta \gamma$ subunits of $\mathrm{G}_{-}$proteins and $\mathrm{Ca}^{2+} \mathrm{channels}$ DAMGO-induced PPF was diminished after chronic treatment, suggesting disruption of G-protein-channel interactions. Such disruption could occur at the postreceptor level, because chronic DAMGO also reduced GTP $\gamma S$-induced PPF that was independent of receptor activation. Again, inhibition of PI3K or MAPK reduced desensitization of PPF. Our data suggest that the PI3Kcascade involving MAPK and Akt enhances $\mu$-opioid desensitization via postreceptor modifications that interfere with G-protein-effector interactions.

Key words: PI 3-kinase; $\mathrm{Ca}^{2+}$ channel; opioid; desensitization; Akt; PTEN

\section{Introduction}

A common feature of signaling through G-protein-coupled receptors (GPCRs) is the development of desensitization after excessive stimulation of the receptor. In non-neuronal cells, GPCR desensitization is often associated with receptor phosphorylation, which uncouples the receptor from G-proteins and initiates receptor internalization and recycling (Law et al., 2000; Claing et al., 2002). In neurons, the exact role of these events in functional desensitization remains unclear. Adding on another layer of complexity, desensitization of GPCR signaling can also result from changes at postreceptor components such as G-proteins, effectors, or their regulators. One example is opioid modulation of ion channels. Activation of $\mu$-opioid receptors coupled to $\mathrm{G}_{\mathrm{i}}$ and $\mathrm{G}_{\mathrm{o}}$ leads to inhibition of voltage-gated $\mathrm{Ca}^{2+}$ channels (VGCCs) and activation of G-protein-coupled inwardly rectify-

Received June 11, 2003; revised Sept. 16, 2003; accepted Sept. 20, 2003.

This work was supported by National Institutes of Health Grants P50DA05010 (component 4) and R01AG17542 to C.W.X. and NS38489 to X.L. We thank Drs. C. J. Evans and T. G. Hales for valuable discussion and comments on this manuscript, D. Zhao for technical support, and L. Lin for initial pilot experiments.

Correspondence should be addressed to Cui-Wei Xie, Department of Psychiatry and Biobehavioral Sciences, Neuropsychiatric Institute, University of California at Los Angeles, 760 Westwood Plaza, Los Angeles, CA 90024 1759. E-mail: cxie@mednet.ucla.edu.

Copyright $\odot 2003$ Society for Neuroscience 0270-6474/03/2310292-10\$15.00/0 ing potassium channels (GIRKs). Both actions involve direct interactions between G-protein $\beta \gamma$ subunits $(\mathrm{G} \beta \gamma)$ and ion channels in a membrane delimited manner (Bourinet et al., 1996; Dascal, 2001). Modulation of opioid receptors leads to homologous desensitization, whereas factors interfering with G-proteinchannel interactions confer the heterologous nature of desensitization (Murthy et al., 2000; Blanchet and Luscher, 2002). Both homologous and heterologous desensitization have been observed with regard to opioid modulation of GIRK (Kovoor et al., 1995; Alvarez et al., 2002) or VGCC (Samoriski and Gross, 2000; Borgland et al., 2003), indicating that opioid desensitization may occur at different levels or sites of the receptor-G-protein-channel pathway. Specific signaling mechanisms underlying these different forms of opioid desensitization, however, have not been fully understood in neurons.

Recent studies show that GPCRs modulate neuronal $\mathrm{Ca}^{2+}$ channels through assembly of the receptor, channel, and G-protein signal complex. The second messenger-generating enzyme, protein kinase, and counteracting phosphatase are tightly linked with the complex to enable specific and rapid regulation of the channels (Davare et al., 2001). It is intriguing to examine how interactions between the GPCR, G-protein, and $\mathrm{Ca}^{2+}$ channel are evolved through cross talk with associated signaling systems 
during a regulatory process such as desensitization. The present study explored this issue by investigating the role of phosphoinositide 3-kinase (PI3K) cascade in desensitization of $\mu$-opioid modulation of VGCC in mouse dorsal root ganglion (DRG) neurons. PI3K comprises a family of lipid kinases. Their inositol lipid products are key mediators of intracellular signaling. The p110 catalytic subunit of PI3K can be directly activated by G $\beta \gamma$ dimers liberated after activation of GPCRs (Hawes et al., 1998; LopezIlasaca, 1998; Garcia-Caballero et al., 2001). Subsequent generation of phosphatidylinositol (PtdIns)-3,4- $\mathrm{P}_{2}$ and PtdIns-3,4,5- $\mathrm{P}_{3}$ $\left(\mathrm{PIP}_{3}\right)$ initiates multiple signaling pathways. One of the key downstream targets of PI3K signaling is the serine-threonine kinase Akt, the activity of which is negatively regulated by phosphatase and tensin homolog (PTEN), a lipid phosphatase that reduces the cellular level of $\mathrm{PIP}_{3}$ (Toker, 2000; Cantrell, 2001). The PI3K-Akt pathway and PTEN have been studied extensively as regulators of cell growth, differentiation, and survival, but their roles in cell functionremain unknown. We demonstrate here that persistent activation of the PI3K-Akt pathway and its cross talk with mitogen-activated protein kinase (MAPK) are essential for the development of chronic opioid desensitization in sensory neurons.

\section{Materials and Methods}

$D R G$ cultures. Dorsal root ganglia were excised from postnatal day 0 (P0)-P3 C57 black 6 mice. The ganglia were enzymatically dissociated for 30 min with S-MEM medium containing $0.25 \%$ trypsin at $37^{\circ} \mathrm{C}$. Neurons were then dissociated mechanically by trituration using fire-polished Pasteur pipettes. Dissociated cells were plated at a density of $1 \times 10^{5}$ cells $/ \mathrm{cm}^{2}$ onto glass coverslips coated with poly-L-ornithine (Sigma, St. Louis, MO) and laminin (Invitrogen, Grand Island, NY) and mounted to the bottom of $35 \mathrm{~mm}$ culture dishes. The cultures were maintained at $37^{\circ} \mathrm{C}$ in $5 \% \mathrm{CO}_{2}$ and fed with serum-free Neurobasal-A media supplemented with B-27, L-glutamine, 2.5s nerve growth factor (NGF) $(0.1$ $\mu \mathrm{g} / \mathrm{ml}$; Invitrogen $)$ and 5 -fluoxy-D-uridine $(0.1 \mathrm{mg} / \mathrm{ml}$; Sigma), which inhibits proliferation of non-neuronal cells. To avoid MAPK activation by NGF before experiments, DRG cultures were washed and kept in NGF-free medium for $2 \mathrm{hr}$ before electrophysiological recordings and other assays were started.

Electrophysiology. Whole-cell $\mathrm{Ca}^{2+}$ currents were recorded from DRG neurons of $20-30 \mu \mathrm{m}$ diameter maintained in cultures for $2-7 \mathrm{~d}$. Experiments were conducted under voltage-clamp conditions at room temperature with an Axopatch 1-D patch-clamp amplifier. During recording, cells were perfused continuously with an external solution containing 10 $\mathrm{mm} \mathrm{CaCl}_{2}, 130 \mathrm{~mm}$ tetraethylammonium chloride, 5 mM HEPES, $25 \mathrm{~mm}$ D-glucose, and $0.25 \mu \mathrm{M}$ tetrodotoxin, $\mathrm{pH}$ 7.35. The patch electrode of 1-2 $\mathrm{M} \Omega$ resistance was filled with an internal solution composed of the following (in mM): $105 \mathrm{CsCl}, 40 \mathrm{HEPES}, 5 \mathrm{D}$-glucose, $2.5 \mathrm{MgCl}_{2}$, $10 \mathrm{EGTA}$, $2 \mathrm{Mg}$-ATP, and $0.5 \mathrm{GTP}, \mathrm{pH}$ 7.2. High voltage-activated $\mathrm{Ca}^{2+}$ currents were evoked every $10 \mathrm{sec}$ by $100 \mathrm{msec}$ voltage steps to $+10 \mathrm{mV}$ from a holding potential of $-80 \mathrm{mV}$. Capacitance and series resistance were corrected with the compensation circuitry on the amplifier. Series resistance was compensated by $80-90 \%$. Leak currents were subtracted using a $\mathrm{P} / 6$ protocol. Currents were filtered at $2 \mathrm{kHz}$, digitized at $5 \mathrm{kHz}$, and saved onto the hard disk of a computer for off-line analysis.

Recorded signals were acquired and analyzed using Axon Instruments (Foster City, CA) pCLAMP v8.0 software. The amplitude and time of peak $\mathrm{Ca}^{2+}$ currents were determined using the peak detect feature of the software. Under control conditions, the whole-cell $\mathrm{Ca}^{2+}$ current typically reached its peak amplitude $15-25 \mathrm{msec}$ after the start of voltage steps, with an average time-to-peak of $19.5 \pm 0.8 \mathrm{msec}(n=45)$. To avoid influence by potential changes in the time-to-peak, the amplitude of inward current was measured at the time of its peak during each voltage step. After breaking into the whole-cell mode, currents were allowed to stabilize for up to $2 \mathrm{~min}$. The baseline value of peak current amplitude was then determined by averaging 6-10 repeated measurements before drug applications. [D-Ala ${ }^{2}, \mathrm{~N}-\mathrm{MePhe}^{4}, \mathrm{Gly}^{-\mathrm{ol}^{5}}{ }^{5}$-enkephalin (DAMGO)and other drug-induced current inhibition was measured as the maximal reduction in peak current amplitudes during drug perfusion and expressed as percentage changes from baseline. Cells were excluded if they exhibited continuous current rundown $(>2 \%$ per min) during baseline collection or if the amplitude of peak currents failed to recover from DAMGO-induced reduction after removal of the agonist. Less than 5\% of cells recorded were excluded according to the above criteria. Prepulse facilitation (PPF) was expressed as a ratio of peak current amplitudes induced by two test pulses, $\mathrm{P} 2$ versus $\mathrm{P} 1$; both pulses were identical except that $\mathrm{P} 2$ was preceded at a $10 \mathrm{msec}$ interval by a $40 \mathrm{msec}$ depolarizing prepulse from -80 to $+80 \mathrm{mV}$. All data are presented as mean \pm SE. One-way ANOVA and Student's $t$ tests were used for statistical analysis. Statistical significance was defined as $p<0.05$.

Drug application and desensitization protocols. DAMGO and kinase inhibitors (Sigma) were prepared as $1 \mathrm{~mm}$ stock solutions in water or D-methyl-sulfoxide and diluted with external solution to desired final concentrations before application. During recording, the external solution was applied continuously at $2 \mathrm{ml} / \mathrm{min}$ through a $1 \mathrm{ml}$ recording chamber carrying the culture coverslip. The perfusion pipette was positioned near the cell under recording for fast washing on and off of the drug. When testing the acute DAMGO effect, cells were first perfused with drug-free solution to establish the baseline and then with $1 \mu \mathrm{M}$ DAMGO for 1-2 min to observe the maximal reduction of $\mathrm{Ca}^{2+}$ currents. To avoid desensitization caused by repeated or prolonged exposure to the $\mu$ agonist, only one or two cells per culture dish were tested, and each cell received a single application of DAMGO for no longer than $2 \mathrm{~min}$, followed by extensive washing.

In acute desensitization experiments, DAMGO perfusion was continued for up to $7 \mathrm{~min}$ to allow gradual recovery of $\mathrm{Ca}^{2+}$ currents from the initial reduction. The extent of acute desensitization was expressed by the percentage reduction of opioid responses from the initial level in the same cells. To determine the effect of kinase inhibitors on acute desensitization, cultures were pretreated with the inhibitor alone for $1 \mathrm{hr}$ before recording and then perfused with both DAMGO and the inhibitor during the recording. In chronic desensitization experiments, DRG cultures were pretreated for 1,4 , or $24 \mathrm{hr}$ with $1 \mu \mathrm{M}$ DAMGO added into NGF-free culture medium with or without kinase inhibitors. The drugcontaining medium was then removed, and cells were thoroughly washed three times with the external solution. $\mathrm{Ca}^{2+}$ current recordings were conducted immediately after washing to determine the effect of an acute test dose of DAMGO $(1 \mu \mathrm{M}, 1 \mathrm{~min})$. The extent of chronic desensitization was assessed by comparing acute DAMGO responses of pretreated neurons with untreated neurons.

Phospho-Akt immunohistochemistry. DRG cultures were fixed in icecold $4 \%$ paraformaldehyde for $15 \mathrm{~min}$, washed three times with PBS, blocked, and permeabilized with a blocking buffer containing $10 \%$ goat serum and $0.3 \%$ Triton X-100 for $30 \mathrm{~min}$. The primary antibody, phospho-Akt (Ser-473) polyclonal antibody (1:100; Cell Signaling Technology, Beverly, MA), was applied for $1 \mathrm{hr}$ at room temperature, followed by washes with PBS and additional incubation with a Cy2-conjugated goat anti-rabbit second antibody (1:250; The Jackson Laboratory, Bar Harbor, ME) for $1 \mathrm{hr}$. After washing, the cultures were mounted with Vector Shield mounting medium containing nuclear $4^{\prime}, 6^{\prime}$-diamidino-2phenylindole (DAPI) counterstain and imaged with an inverted fluorescence microscope (Olympus Optical, Tokyo, Japan). Images were captured with a digital camera (Hamamatsu Photonic, Bridgewater, NJ) and saved with Image-Pro plus software.

Immunoblotting analysis. Dorsal root ganglia were sonicated and lysed in buffer containing $1 \times$ PBS, $1 \%$ Nonidet P-40, $0.5 \%$ sodium deoxycholate, $0.1 \%$ SDS, $100 \mu \mathrm{g} / \mathrm{ml}$ PMSF, $1 \mathrm{mg} / \mathrm{ml}$ aprotinin, $500 \mu \mathrm{g} / \mathrm{ml}$ leupeptide, and $1 \mathrm{~mm}$ sodium orthovanadate. The lysates were centrifuged at $10,000 \times g$ for $15 \mathrm{~min}$ at $4^{\circ} \mathrm{C}$. Supernatants were separated, and protein concentrations were determined by Bradford assay using BSA as a standard. Proteins (30 $\mu \mathrm{g}$ per lane) were separated on $10 \%$ SDS-PAGE, transferred to nitrocellulose membranes, blocked with $5 \%$ milk protein, and incubated with primary antibodies overnight at $4^{\circ} \mathrm{C}$. Antibodies for PTEN, phospho-Akt (Ser-473), and total Akt were purchased from New England Biolabs (Beverly, MA) and used at 1:1000.

PTEN knock-out mice. Generation of PTEN - / - mice (Nestin Cre ${ }^{+/-}$ Pten $^{\text {loxp } / \Delta 5}$ ) has been reported previously (Groszer et al., 2001). Briefly, 
exon 5 of the Pten gene was flanked with loxp sequences (Pten ${ }^{\text {loxp}}$ ). Pten ${ }^{\text {loxp/loxp }}$ females were crossed with males carrying a nestin promoterdriven Cre transgene $\left(\mathrm{Cre}^{+/-}\right)$that was activated in neural stemprogenitor cells at embryonic day 9 or 10, resulting in almost complete gene deletion in neural tissues by midgestation. To ensure complete deletion of PTEN, we generated Pten ${ }^{\text {loxp } / \Delta 5} \mathrm{Cre}^{+/-}$mice carrying a conventional exon 5-deleted allele $\left(P \operatorname{ten} \Delta^{5}\right)$ and a Pten ${ }^{\operatorname{loxp}}$ allele. In DRG tissue from P0 pups, no PTEN protein could be detected by immunoblotting, indicating a nearly complete deletion of PTEN (see Fig. 6A). DRG cultures derived from P0 PTEN-/- mice and their wild-type littermates were maintained in separate culture dishes. Electrophysiological and immunohistochemical studies were performed using cells of both genotypes in a blind manner.

\section{Results}

\section{DAMGO inhibition of voltage-gated $\mathrm{Ca}^{2+}$ currents and} development of desensitization

Previous studies in rat DRG neurons showed that $\mu$-opioids inhibited high voltage-activated $\mathrm{Ca}^{2+}$ currents composed of primarily N-type currents (Rusin and Moises, 1995; Womack and McCleskey, 1995). We observed similar opioid action in mouse DRG neurons. Depolarizing voltage steps from -80 to $+10 \mathrm{mV}$ elicited rapid inward currents in these neurons, and the amplitude of peak inward current was reversibly reduced by brief exposure to the $\mu$ agonist DAMGO (Fig. $1 A$ ). The average current reduction by acute application of DAMGO $(1 \mu \mathrm{M}, 1 \mathrm{~min})$ was $55 \pm 3 \%$ in 62 neurons tested. In cells pretreated with a specific $\mu$ receptor antagonist, $\mathrm{Cys}^{2}, \mathrm{Tyr}^{3}, \mathrm{Arg}^{5}, \mathrm{Pen}^{7}$-Amide (CTAP) (1 $\mu \mathrm{M}, 30 \mathrm{~min})$, DAMGO application in the presence of CTAP produced negligible current inhibition $(4 \pm 1 \% ; n=7)$, confirming the receptor specificity of DAMGO action (Fig. 1C). Blocking $\mathrm{N}$-type channels with $\omega$-conotoxin GVIA ( $5 \mu \mathrm{M}, 2 \mathrm{~min})$ attenuated total $\mathrm{Ca}^{2+}$ currents by $51 \pm 6 \%$ and dramatically reduced current inhibition by subsequent DAMGO application (16 $\pm 3 \%$ with the toxin vs $66 \pm 4 \%$ without the toxin; $n=9 ; p<0.01$ ) (Fig. $1 C)$. This suggests that $\mathrm{N}$-type currents constitute the major component $(\sim 76 \%)$ of DAMGO-sensitive currents in mouse DRG neurons.

DRG cultures consist of a mixed population of neurons of various sizes. Studies on rat DRG neurons show that expression of $\mu$ receptors is at the highest level across the entire cell diameter range during the first postnatal week and then declines in larger cells and is confined mainly to small and medium cells by P21 (Beland and Fitzgerald, 2001). Correspondingly, only a subset of DRG neurons is sensitive to DAMGO in cultures derived from adult rats (Schroeder and McCleskey, 1993). Consistent with this developmental pattern, our cultures derived from $\mathrm{P} 0-\mathrm{P} 3$ neonatal mice yielded a high percentage of DAMGO-sensitive cells at all cell sizes. Of 62 control cells with diameters of $20-30 \mu \mathrm{m}, 93 \%$ responded to a test dose of DAMGO $(1 \mu \mathrm{M}, 1 \mathrm{~min})$ with rapid, $>10 \%$ reduction in the amplitude of peak $\mathrm{Ca}^{2+}$ currents. Such a high frequency of agonist responses thus allowed reliable detection of opioid desensitization in our preparations.

Acute DAMGO desensitization was observed while recording with continuous perfusion of $1 \mu \mathrm{M}$ DAMGO. Inhibition of $\mathrm{Ca}^{2+}$ current usually reached the maximum within the first minute of DAMGO exposure and then decreased gradually over a course of 3-7 min (Fig. 1 A,B). The average current inhibition was $37 \pm 6 \%$ at the end of DAMGO perfusion, significantly smaller than the initial current inhibition in the same cells ( $58 \pm 6 \%$; $n=12$; $p<$ 0.01) (Fig. 1C).

Chronic desensitization was induced by prolonged incubation with DAMGO (Fig. $2 A, B$ ). After 1, 4, or 24 hr pretreatment, an acute test dose of DAMGO $(1 \mu \mathrm{M}, 1 \mathrm{~min})$ reduced peak $\mathrm{Ca}^{2+}$
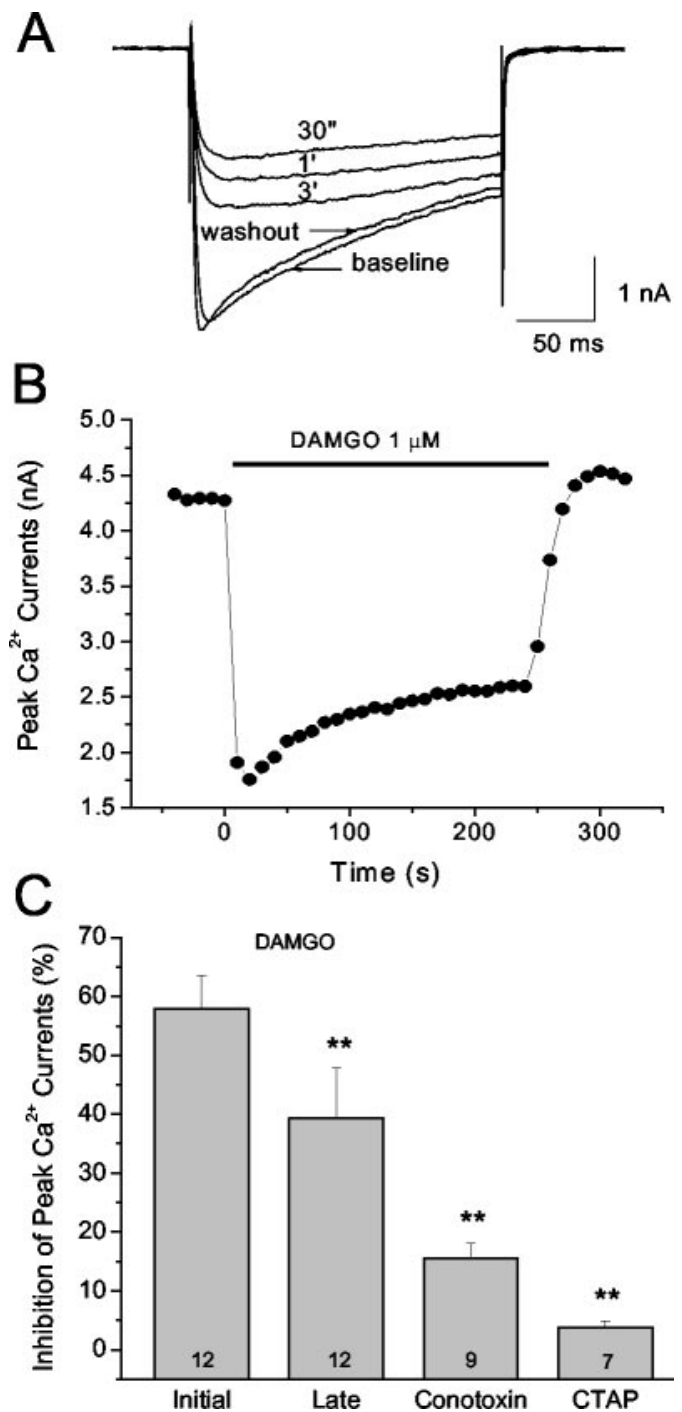

Figure 1. Acute desensitization of $\mu$-opioid inhibition of voltage-gated $\mathrm{Ca}^{2+}$ currents. The $\mu$ agonist DAMGO was used at $1 \mu \mathrm{m}$ in all experiments shown in this and the following figures. $A$, Representative recordings from a DRG neuron while continuously perfused with DAMGO. Whole-cell $\mathrm{Ca}^{2+}$ currents were evoked by $100 \mathrm{msec}$ voltage steps from -80 to $+10 \mathrm{mV}$. Note the partial loss of current inhibition at 1 and 3 min compared with the initial response at $30 \mathrm{sec}$ and full recovery of $\mathrm{Ca}^{2+}$ currents after washout of DAMGO. B, A complete time course of acute desensitization in this neuron. $C$, Group data showing significant reduction of DAMGO-induced responses at the end of a 3-7 min perfusion (Late) compared with the maximal responses during the first minute in the same cells (Initial). The initial DAMGO response could be mostly eliminated by the N-type current blocker $\omega$-conotoxin GVIA (Conotoxin; $5 \mu \mathrm{m}$ ) or completely blocked by a selective $\mu$ antagonist, CTAP $(1 \mu \mathrm{M})$. Cells were exposed to the toxin for 2 min or to CTAP for $30 \mathrm{~min}$ before DAMGO was coapplied for $1 \mathrm{~min}$. The number of cells in each group is displayed at the bottom of the column. ${ }^{* *} p<0.01$ compared with the initial DAMG0 response in control cells.

currents by $23 \pm 4,18 \pm 2$, or $7 \pm 2 \%(n=10-17)$, respectively, all being significantly smaller than responses of untreated neurons $(0 \mathrm{hr} ; 55 \pm 3 \% ; n=62 ; p<0.01)$. After a $24 \mathrm{hr}$ pretreatment, the acute test dose induced $<10 \%$ current reduction in $82 \%$ of treated cells. Despite the nearly complete loss of DAMGO responsiveness in these cells, chronic desensitization appeared to be reversible, with acute DAMGO responses recovered to $38 \pm 3 \%$ at $4 \mathrm{hr}$ after removal of DAMGO (Fig. $2 A, B$ ).

We then examined whether chronic DAMGO desensitization attenuated responses mediated by other $G_{i^{-}}$and $G_{o}$-coupled receptors. Inhibition of $\mathrm{Ca}^{2+}$ currents by the $\mathrm{GABA}_{\mathrm{B}}$ agonist 


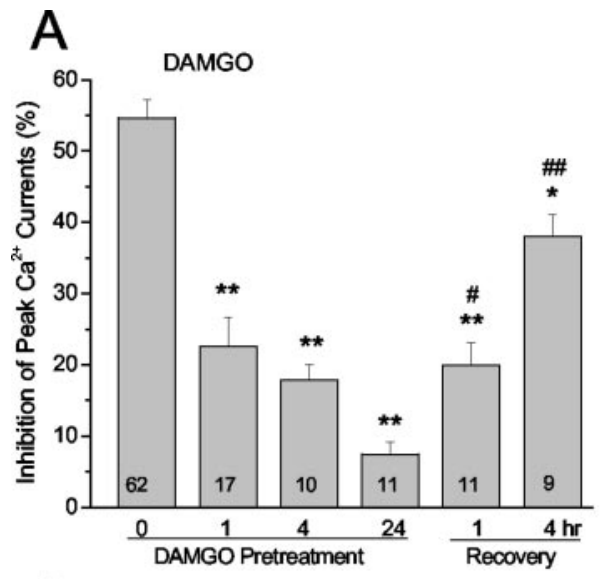

B
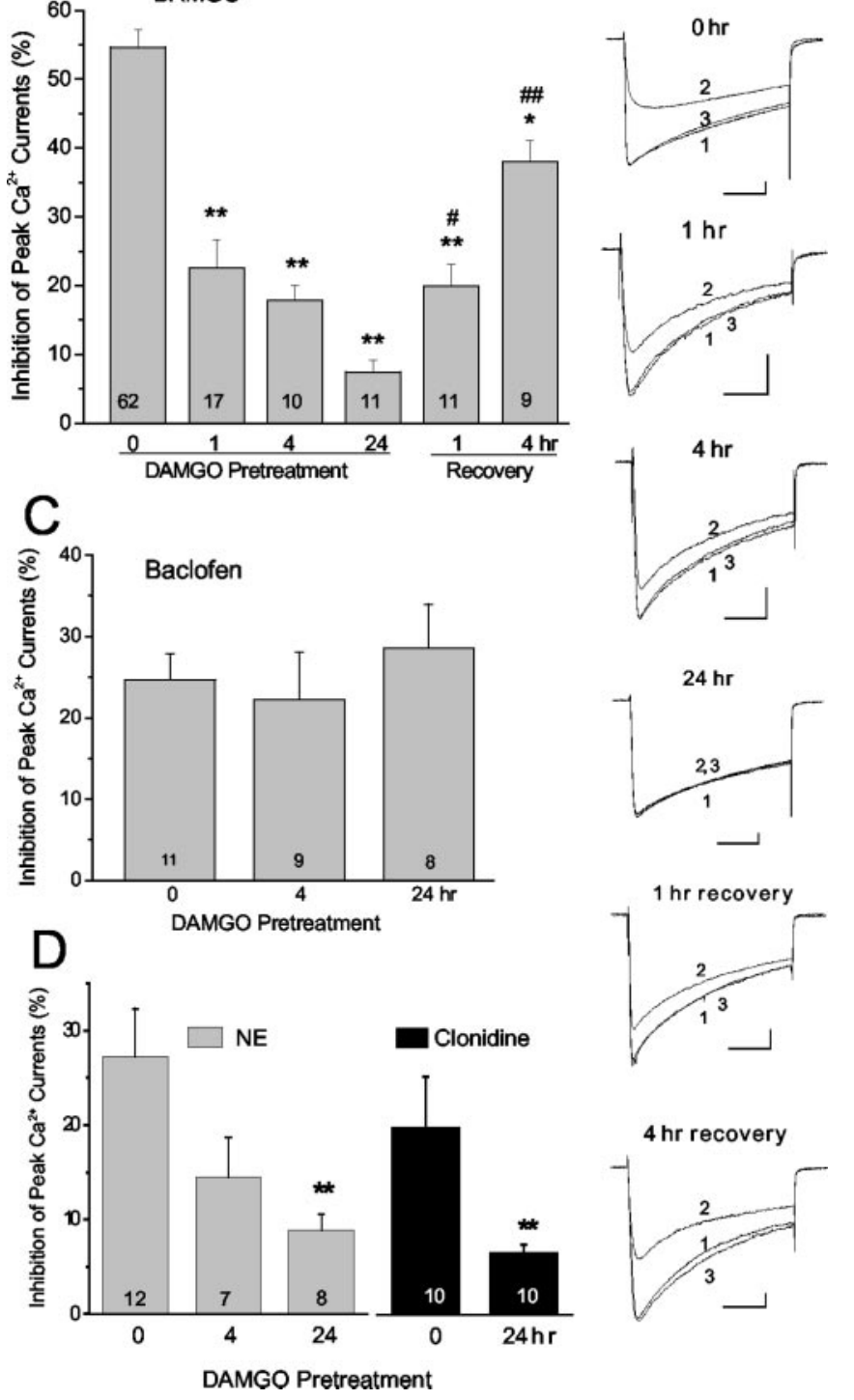

$1 \mathrm{hr}$ recovery
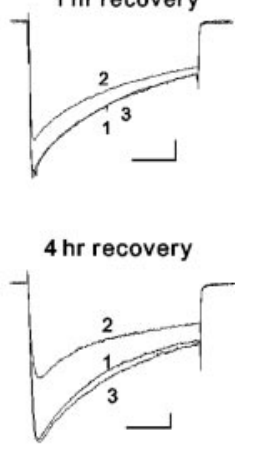

Figure 2. Chronic desensitization of $\mu$-opioid action. $A$, The time course of desensitization and recovery. The effect of an acute test dose of DAMGO $(1 \mu \mathrm{M}, 1 \mathrm{~min})$ was gradually diminished after 1,4 , or $24 \mathrm{hr}$ pretreatment with the agonist. Removal of DAMGO for 1 or $4 \mathrm{hr}$ after the $24 \mathrm{hr}$ pretreatment resulted in partial recovery of DAMGO responses. Each time point used a different group of cells. ${ }^{*} p<0.05$ and ${ }^{* *} p<0.01$ compared with untreated neurons $(0 \mathrm{hr}) .{ }^{*} p<0.05$ and ${ }^{\# \#}<<0.01$ compared with the $24 \mathrm{hr}$ DAMG0 group. $B$, Representative current recordings for each group, collected before (1), during (2), and after (3) the acute test dose of DAMGO. Calibration: $0.5 \mathrm{nA}, 50$ msec. C, D, DAMGO pretreatment for 4 or $24 \mathrm{hr}$ did not affect current inhibition by the $\mathrm{GABA}_{\mathrm{B}}$ agonist baclofen but heterologously reduced the effect of NE or the $\alpha_{2}$ adrenergic agonist clonidine. Baclofen $(50 \mu \mathrm{M}), \mathrm{NE}(10 \mu \mathrm{M})$, or clonidine $(10 \mu \mathrm{M})$ was acutely applied for 1 min after DAMGO pretreatment. ${ }^{* *} p<0.01$ compared with untreated neurons (0 hr).

baclofen (50 $\mu \mathrm{M}, 1 \mathrm{~min})$ was compared in cells pretreated with 1 $\mu \mathrm{M}$ DAMGO for 0,4 , or $24 \mathrm{hr}$. No significant difference was observed among these groups (Fig. $2 C$ ). In contrast, DAMGO pretreatment reduced norepinephrine (NE)-mediated current inhibition in a time-dependent manner (Fig. 2D). In untreated neurons, inhibition of $\mathrm{Ca}^{2+}$ currents by $\mathrm{NE}(10 \mu \mathrm{M}, 1 \mathrm{~min})$ was mostly reversed by coapplication of the $\alpha_{2}$ adrenergic antagonist yohimbine at $1 \mu \mathrm{M}(12 \pm 2 \% ; p<0.05$ compared with $27 \pm 5 \%$ without yohimbine; $n=9$ and 12), suggesting involvement of $\alpha_{2}$ receptors in NE action. We further tested the action of clonidine, a selective $\alpha_{2}$ agonist. Acute application of clonidine (10 $\mu \mathrm{M}, 1$ min) elicited a $19 \pm 5 \%$ current reduction $(n=10)$, which was reversed by yohimbine $(5 \pm 2 \% ; n=10 ; p<0.05)$. The effect of clonidine was also heterologously reduced by a $24 \mathrm{hr}$ DAMGO pretreatment (Fig. 2D). These results suggest that chronic DAMGO desensitization is homologous to $\mathrm{GABA}_{\mathrm{B}}$-mediated responses but heterologous to $\alpha_{2}$ adrenergic responses.

\section{Blocking PI3K and MAPK activity attenuates chronic but not acute DAMGO desensitization}

To determine the signaling pathways mediating DAMGO desensitization, we examined the effect of several kinase inhibitors on acute and chronic desensitization (Fig. 3). LY294002 (Vlahos et al., 1994) and wortmannin (Ui et al., 1995) were used to block PI3K activity. The MAP kinase kinase (MEK) inhibitor PD98059 was used to prevent activation of MAPK (Alessi et al., 1995). At the concentrations that we used, these drugs reportedly are highly selective and potent inhibitors for the specified kinase, yet they did not affect acute DAMGO desensitization. In the presence of $10 \mu \mathrm{M}$ LY294002 or PD98059, DAMGO-induced responses decayed to $67 \pm 5 \%(n=10)$ or $69 \pm 5 \%(n=13)$ of the initial level within 3-7 min of perfusion, which is not significantly different from that seen in the absence of inhibitors ( $63 \pm 9 \% ; n=12 ; p>$ $0.05)$. Chronic DAMGO desensitization, however, was significantly reduced by PI3K or MAPK inhibitors. When LY294002 (10 $\mu \mathrm{M})$ or wortmannin $(1 \mu \mathrm{M})$ was added during DAMGO pretreatment, acute DAMGO responses remained at $34 \pm 4$ or $30 \pm 4 \%$ after $4 \mathrm{hr}$, both significantly greater than that in cells pretreated with DAMGO alone $(18 \pm 2 \% ; p<0.01)$. Coapplication of 1,10 , or $50 \mu \mathrm{M}$ PD98059 with DAMGO reduced the desensitization in a dose-dependent manner (Fig. 3A). Acute application of LY294002 or PD98059 (10 $\mu \mathrm{M}, 2 \mathrm{~min})$ caused no evident changes in $\mathrm{Ca}^{2+}$ currents, and a $4 \mathrm{hr}$ pretreatment with either inhibitor alone did not alter cell responses to acute DAMGO perfusion (Fig. 3C). The results indicate that PI3K and MAPK neither have a tonic influence on baseline $\mathrm{Ca}^{2+}$ currents nor do they interfere with acute opioid responses in DRG neurons. Attenuation of chronic desensitization by their inhibitors thus may result from blockade of mechanisms specifically required for the development of chronic desensitization.

The effect of kinase inhibitors was further assessed at different time points of chronic desensitization (Fig. 3B). At all time points tested, acute DAMGO perfusion induced significantly greater current inhibition in cells co-pretreated with $10 \mu \mathrm{M}$ LY294002 or PD98059 compared with those with DAMGO alone. The reversal of desensitization by either inhibitor was incomplete, and a combined application of both inhibitors yielded no additive effect. At $4 \mathrm{hr}$, acute DAMGO responses in cells pretreated with both inhibitors was $31 \pm 6 \%(n=9)$, which is not significantly different from those pretreated with LY294002 (34 $\pm 4 \%$; $n=13)$ or PD98058 alone $(30 \pm 2 \% ; n=10)$. These results suggest that both PI3K and MAPK are critically involved in mediating chronic desensitization and likely to act in a serial rather than parallel pathway.

\section{Chronic DAMGO attenuates G $\boldsymbol{\beta} \gamma$-mediated prepulse} facilitation in a PI3K- and MAPK-dependent manner Inhibition of VGCC currents by GPCRs involves both voltagedependent and independent mechanisms (Luebke and Dunlap, 1994). The voltage-dependent action requires direct binding of $\mathrm{G} \beta \gamma$ to the $\mathrm{Ca}^{2+}$ channel. A strong depolarizing prepulse can disrupt this interaction and relieve current inhibition during subsequent test pulse, a phenomenon known as PPF (Herlitze et al., 

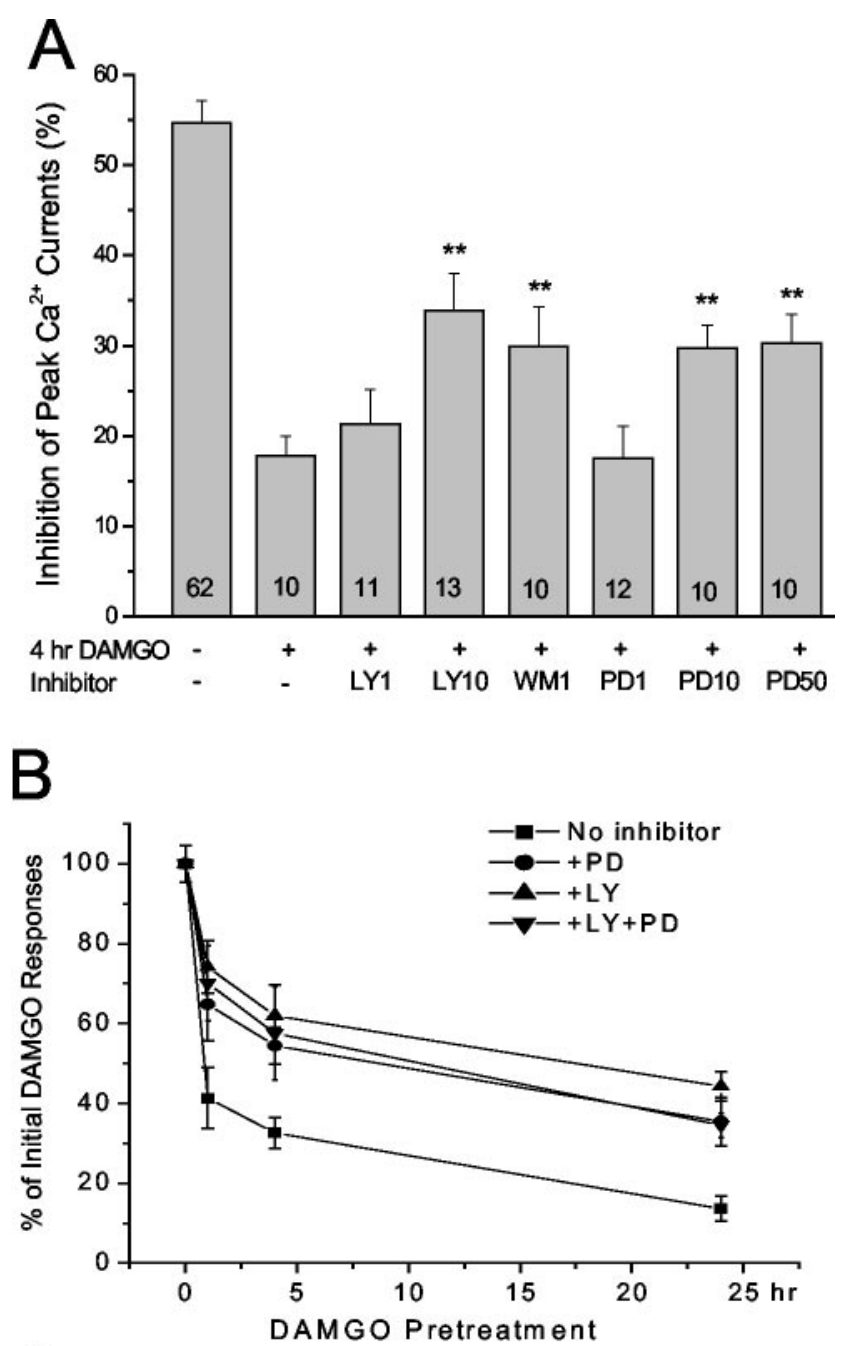

C

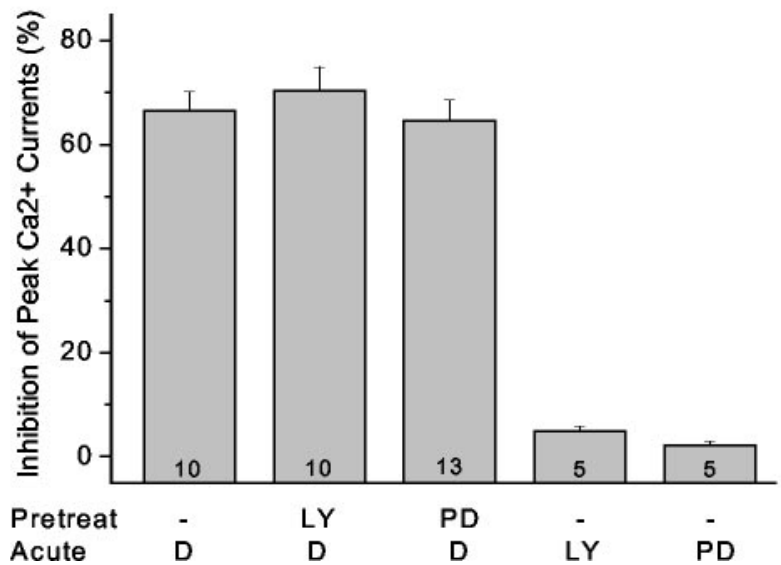

Figure 3. Blocking PI3K or MAPK activity attenuates chronic DAMGO desensitization. $A$, The dose-dependent reduction of chronic desensitization by PI3K or MAPK inhibitors. Desensitization was induced by pretreatment with DAMG0 for $4 \mathrm{hr}$. PD98059 [(PD) 1, 10, or $50 \mu \mathrm{M}$ ], LY294002 [(LY) 1 or $10 \mu \mathrm{m}$ ], or wortmannin [(WM) $1 \mu \mathrm{m}$ ] was added into the culture medium during pretreatment. The results shown are responses elicited by the acute test dose of DAMGO in control and pretreated cells. ${ }^{* *} p<0.01$ compared with cells pretreated with $4 \mathrm{hr}$ DAMGO alone. $B$, The time course of chronic desensitization in the presence of PI3K and MAPK inhibitors. Acute DAMGO effect at different time points was normalized to the value of control cells receiving no pretreatment (0 hr). LY294002 and PD98059 were applied at $10 \mu \mathrm{m}$ during DAMGO pretreatment. Note the lack of additive effect when both were applied simultaneously compared with either inhibitor alone ( $n=9-62$ for each time point.) C, Lack of effect of PI3K
1996). Using the PPF test, we assessed changes in $\mathrm{G} \beta \gamma-\mathrm{Ca}^{2+}$ channel interactions during acute and chronic DAMGO desensitization (Fig. 4). Control cells showed little PPF in the absence of DAMGO, suggesting lack of tonic inhibition of $\mathrm{Ca}^{2+}$ currents by $\mathrm{G} \beta \gamma$ in DRG neurons (baseline P2/P1 $=0.97 \pm 0.01 ; n=16$ ). During acute DAMGO perfusion, cells displayed evident PPF (1.41 \pm 0.09$)$ because of partial reversal of current inhibition by the prepulse ( $25 \pm 7 \%$ with prepulse vs $45 \pm 7 \%$ without prepulse; $p<0.01)$. This facilitation was completely lost after a $4 \mathrm{hr}$ DAMGO pretreatment $(0.97 \pm 0.02 ; n=11)$ but could be partially rescued in cells cotreated with $10 \mu \mathrm{M}$ LY294002 or PD98058 ( $1.08 \pm 0.04$ and $1.07 \pm 0.02$ vs $0.97 \pm 0.01$ in the DAMGO alone group; $n=11-16 ; p<0.05$ for both comparisons). These data suggest that chronic DAMGO causes desensitization of G $\beta \gamma$ dependent, voltage-sensitive mechanisms underlying $\mu$-opioid action and that PI3K and MAPK activity contributes to this desensitization.

Chronic DAMGO-induced PI3K and MAPK activity could attenuate PPF via postreceptor mechanisms that directly or indirectly interfere with $G \beta \gamma$-channel interactions or act at the receptor level to reduce G-protein activation. These two possibilities can be distinguished by directly activating G-proteins with a nonhydrolyzable GTP analog (GTP $\gamma S)$. This compound induces PPF without activation of receptors, thus allowing detection of changes at the postreceptor level (Toth et al., 1996; Mark et al., 2000). As shown in Figure 5, when GTP $\gamma S$ was applied intracellularly via whole-cell recording electrodes, a pronounced PPF was developed within a few minutes of recording in control cells $(\mathrm{P} 2 / \mathrm{P} 1=1.68 \pm 0.23$ at $8 \mathrm{~min} ; n=9)$. Subsequent DAMGO application ( $1 \mu \mathrm{M}, 1 \mathrm{~min})$ did not increase PPF further in GTP $\gamma \mathrm{S}$ loaded cells ( $1.61 \pm 0.15 ; n=7)$, suggesting that DAMGO and GTP $\gamma S$ induced PPF via common mechanisms. In chronic DAMGO-treated neurons, GTP $\gamma \mathrm{S}$-induced PPF was significantly smaller and developed at a much slower rate $(1.17 \pm 0.04$ at $8 \mathrm{~min} ; n=7 ; p<0.01$ compared with untreated controls). This cross-desensitization to GTP $\gamma \mathrm{S}$ was partially reversed by $10 \mu \mathrm{M}$ LY294002 or PD98059 added during DAMGO pretreatment ( $1.38 \pm 0.08$ and $1.67 \pm 0.15 ; n=7$ and $11 ; p<0.01$ compared with $4 \mathrm{hr}$ DAMGO alone). These data indicate that PI3K- and MAPK-mediated postreceptor changes contribute to chronic DAMGO desensitization. Pretreatment with $50 \mu \mathrm{M}$ baclofen for 4 or $24 \mathrm{hr}$ did not affect GTP $\gamma$ S-induced PPF (Fig. 5C), suggesting that $\mathrm{GABA}_{\mathrm{B}}$ desensitization may occur at a different level.

PTEN deletion leads to constitutive upregulation of the PI3KAkt pathway and enhancement of chronic desensitization Using a PTEN knock-out mouse model, we further defined the role of PI3K and its downstream signaling pathways in DAMGO desensitization. Deletion of the Pten gene in embryonic stem cells or the brain elevates cellular $\mathrm{PIP}_{3}$ levels and causes constitutive activation of signaling pathways downstream of PI3K, especially the Akt pathway (Sun et al., 1999; Groszer et al., 2001). To determine whether PTEN deficiency leads to enhanced PI3K signaling in peripheral neurons, we measured phospho-Akt levels in DRG neurons from PTEN-/- mice and their wild-type littermates using a phosphorylation site (Ser-473)-specific Akt antibody. Both immunoblotting and immunohistochemical analyses dem-

and MAPK inhibitors on baseline $\mathrm{Ca}^{2+}$ currents or acute DAMGO responses. LY294002 or PD98059 was applied at $10 \mu \mathrm{m}$ either acutely $(2 \mathrm{~min})$ or as pretreatment $(4 \mathrm{hr})$ that was followed by acute DAMGO perfusion for $1 \mathrm{~min}$. 
A Control Acute D $4 \mathrm{hrD}$ $4 \mathrm{hr} \mathrm{D+LY}$
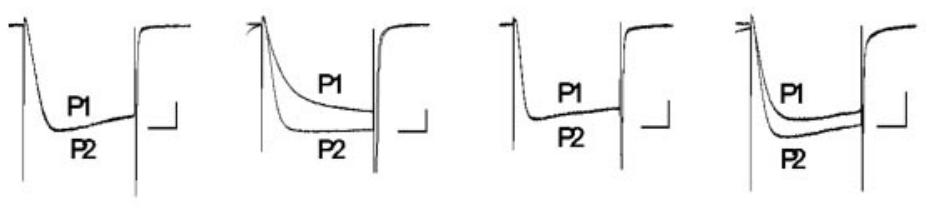

B

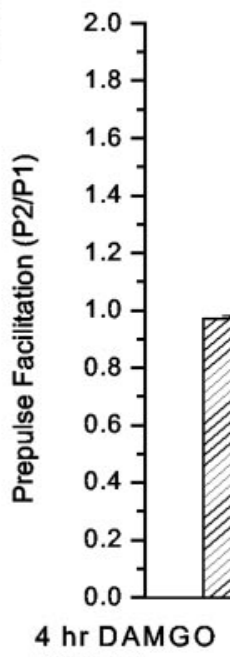
Inhibitor

Figure 4. Chronic desensitization reduces DAMG0-induced PPF. A, Representative recordings of PPF. Ca ${ }^{2+}$ currents elicited by two identical test pulses $(-80$ to $+10 \mathrm{mV}, 40 \mathrm{msec}), \mathrm{P} 1$ and $\mathrm{P} 2$, were superimposed. $\mathrm{P} 2$ was preceded at $10 \mathrm{msec}$ interval by a 40 msec depolarizing prepulse ( -80 to $+80 \mathrm{mV}$; data not shown). Note the increase in the P2/P1 ratio during acute DAMG0 application, complete loss of PPF after a $4 \mathrm{hr}$ DAMG0 pretreatment, and partial rescue of PPF by $10 \mu \mathrm{m}$ LY294002 (LY) or PD98059 (PD). Calibration: $1 \mathrm{nA}, 10 \mathrm{msec}$. B, Group data. PPF was tested in artificial (SF (baseline), during acute application and after washout of DAMG0 in the same neurons. ${ }^{* *} p<0.01$ compared with the baseline value of the same group. ${ }^{\#} p<0.05$ compared with the $4 \mathrm{hr}$ DAMGO alone group.

onstrated much higher levels of phospho-Akt in PTEN - / - neurons than their wild-type counterparts in the absence of DAMGO, indicating constitutive activation of the PI3K-Akt cascade in the mutant neurons (Fig. 6A,B). No significant increases in the phospho-MAPK level were observed in PTEN-/- neurons in the absence of DAMGO.

We then determined whether upregulation of the PI3K-Akt pathway in PTEN -/- neurons altered their responses to acute and chronic DAMGO treatments. Acute DAMGO application (1 $\mu \mathrm{M}, 1 \mathrm{~min})$ reduced $\mathrm{Ca}^{2+}$ currents by $34 \pm 5 \%$ in PTEN $-/-$ neurons $(n=18)$, which was slightly smaller but not significantly different from that in their wild-type counterparts $(46 \pm 5 \%$; $n=$ $21 ; p>0.05)$. The mutant and wild-type neurons also developed acute desensitization at a similar rate, with DAMGO responses decaying by $44 \pm 6$ and $47 \pm 9 \%$, respectively, from the initial levels during continuous perfusion ( $n=9$ and 9; $p>0.05)$. Development of chronic desensitization, however, was significantly different between two genotypes. After a $1 \mathrm{hr}$ pretreatment, $76 \%$ of PTEN-/- neurons (13 of 17) became DAMGO insensitive, whereas only $20 \%$ (3 of 15) of wild-type neurons did so. The average DAMGO response in PTEN $-/-$ cells decreased to $23 \pm 7 \%(n=17)$ of the initial level, much smaller than that in wild-type cells $(53 \pm 8 \% ; n=15 ; p<0.01)$. This accelerated desensitization in PTEN $-/-$ neurons seemed particularly sensi$4 \mathrm{hr} \mathrm{D}+\mathrm{PD}$

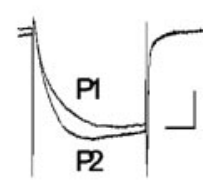

tive to PI3K inhibition and could be reversed to the wild-type level by copretreatment with $10 \mu \mathrm{M}$ LY294002 (Fig. 6C). Interestingly, despite the lack of constitutive activation of MAPK in PTEN -/ - neurons, PD98059 also opposed acceleration of the desensitization (Fig. 6C). These results suggest that upregulation of the PI3K-Akt pathway accelerates development of chronic DAMGO desensitization in DRG neurons, and an intact MAPK activity seems required for the full expression of this accelerated desensitization.

\section{Discussion \\ PI3K and MAPK differentially modulate acute and chronic DAMGO desensitization}

Extensive studies have been conducted to characterize acute opioid actions on VGCC, but few have investigated desensitization of these actions in neurons. Here we observed two different forms of DAMGO desensitization in mouse DRG neurons: an acute, incomplete desensitization occurring within minutes of agonist exposure, and a chronic one leading to nearly complete loss of opioid responses within $24 \mathrm{hr}$. Changes in the activity of PI3K, MAPK, or PTEN selectively altered chronic but not acute desensitization, supporting the view that distinct mechanisms underlie these two forms of desensitization. Acute or rapid desensitization of opioid modulation of VGCC was described previously in rat DRG neurons (Nomura et al., 1994; Samoriski and Gross, 2000) and non-neuronal cells (Kaneko et al., 1997; Morikawa et al., 1998; Borgland et al., 2003). Common features of acute desensitization include rapid onset within minutes, incomplete loss of responses, and often lack of sensitivity to modulators of protein kinase A or C (PKC) as well as to nonspecific inhibitors of protein kinase or phosphatase such as $\mathrm{H}-8$ and okadaic acid. In line with these findings, our results showed that PI3K or MAPK inhibitors did not affect acute desensitization in DRG neurons. Thus, acute opioid desensitization in VGCC modulation seems mediated by phosphorylation-independent mechanisms in many cell types.

In contrast, chronic DAMGO desensitization was significantly reduced by PI3K or MAPK inhibitors and facilitated by upregulation of the PI3K-Akt pathway, suggesting that PI3Kand MAPK-dependent phosphorylation are required for this process. Studies in non-neuronal cells have implicated two major groups of protein kinases in GPCR desensitization: members of the G-protein receptor kinase (GRK) family and second messenger-activated kinases. Receptor phosphorylation by GRKs induces homologous desensitization, in which only the receptors that are activated reduce their responsiveness. This process is often complemented by feedback phosphorylation via second messenger-activated kinases, which does not require receptor occupancy and thus targets both homologous and heterologous 
receptors (Chuang et al., 1996). Heterologous desensitization of GPCR signaling can also result from phosphorylation of postreceptor components such as G-proteins (Fields and Casey, 1995) and effector ion channels (Hamid et al., 1999). Thus, DAMGO desensitization could occur at different levels, including the receptors, $\mathrm{G}$-proteins, and $\mathrm{Ca}^{2+}$ channels. The heterologous reduction of $\mathrm{NE}$ and clonidine actions in chronic DAMGOtreated neurons is consistent with involvement of PI3K and MAPK as second messenger-activated kinases, feedback signals of which may affect heterologous receptors or postreceptor components.

\section{Chronic DAMGO-induced PI3K and MAPK activity alters $\mathrm{G} \boldsymbol{\beta} \boldsymbol{\gamma}-\mathrm{Ca}^{2+}$ channel interactions via postreceptor mechanisms}

Opioid inhibition of VGCC is mediated in part through direct interaction of $\mathrm{G} \beta \gamma$ with $\mathrm{Ca}^{2+}$ channels (Ikeda, 1996; De Waard et al., 1997). The key feature of this inhibition is its voltage dependence, manifested by partial relief of inhibition at large depolarization, which leads to PPF (Womack and McCleskey, 1995). DAMGO-induced PPF was lost after chronic treatment, suggesting weakening of $\mathrm{G} \beta \gamma$-channel interactions during desensitization. This could result from postreceptor modifications directly or indirectly affecting G-protein-channel interactions or from changes at $\mu$ receptors that reduce $\mathrm{G}$-protein activation and $\mathrm{G} \beta \gamma$ liberation. We distinguished these two possibilities by testing the effect of GTP $\gamma \mathrm{S}$ in DAMGO-treated neurons.

Independent of receptor activation, GTP $\gamma S$-induced PPF has been used to determine properties of G-proteins, $\mathrm{Ca}^{2+}$ channels, or their regulators (Parri and Lansman, 1996; Toth et al., 1996; Mark et al., 2000). Here, GTP $\gamma S$-induced PPF was reduced by chronic DAMGO, and this reduction could be prevented by inhibiting PI3K or MAPK. These data indicate that chronic DAMGO may alter properties of postreceptor components in a PI3K- and MAPK-dependent manner. Interestingly, baclofen pretreatment did not affect GTP $\gamma S$-induced PPF. This finding was consistent with lack of cross-desensitization between chronic DAMGO and baclofen, suggesting that their desensitization may occur at different levels. It is likely that baclofen desensitization occurs at the $\mathrm{GABA}_{\mathrm{B}}$ receptor level and, hence, can be bypassed by direct stimulation of G-proteins with GTP $\gamma \mathrm{S}$.

There are several potential targets for DAMGO-induced PI3K and MAPK activity leading to weakening of G $\beta \gamma$-VGCC interactions. First, phosphorylation of $\mathrm{G} \alpha$ by second messengeractivated kinases reduces its affinity for $G \beta \gamma$, thus limiting reassociation of the subunits and signal transduction via heterotrimeric G-proteins (Fields and Casey, 1995). Such changes often affect signaling of multiple GPCRs coupled to the same type(s) of $G_{i}$ and $G_{o}$ (Murthy et al., 2000). Our results showed that chronic DAMGO heterologously reduced responses mediated by $\alpha_{2}$ adrenergic receptors coupled to both $G_{i}$ and $G_{o}$ (Di-
verse-Pierluissi et al., 1995) but not that mediated by $\mathrm{GABA}_{\mathrm{B}}$ receptors coupled to $G_{o}$ (Kajikawa et al., 2001). This desensitization profile could be explained by selective phosphorylation of $\mathrm{G} \alpha_{\mathrm{i}}$ but not $\mathrm{G} \alpha_{\mathrm{o}}$ by PI3K or MAPK. Second, regulators of Gprotein signaling (RGS) are known to accelerate the rate of GTP hydrolysis and promote desensitization of $G_{i}$ and $G_{o}$ (Dohlman and Thorner, 1997; Diverse-Pierluissi et al., 1999). RGS phosphorylation at a consensus MAPK site enhances its function (Garrison et al., 1999). Hence, MAPK-mediated RGS phosphorylation might be a contributing factor to desensitization at the G-protein level. Third, the $\mathrm{Ca}^{2+}$ channel itself could be subject to phosphorylation and desensitization. Activation of PKC upregulates N-type currents and desensitizes subsequent DAMGO responses in rat DRG neurons (King et al., 1999). Such actions result from phosphorylation of $\mathrm{N}$-type channels at the $\alpha 1$ subunit domain I-II linker, which prevents subsequent G $\beta \gamma$ binding within the same region (Zamponi et al., 1997; Hamid et al., 1999). Activation of MAPK also upregulates N-type currents (Lei et al., 1998; Fitzgerald, 2000). Whether this is because of modification of specific channel sites remains to be determined. Finally, our data do not rule out PI3K- or MAPK-mediated changes in opioid receptors or their regulators. The extracellular signalregulated kinases reportedly mediate agonist-induced phosphorylation of $\mu$ receptors (Schmidt et al., 2000) and $\beta$-arrestin (Lin et al., 1999). These changes could facilitate receptor uncoupling from G-proteins or inhibit $\beta$-arrestin-dependent receptor internalization and resensitization, thus having a complex impact on functional desensitization. 
A

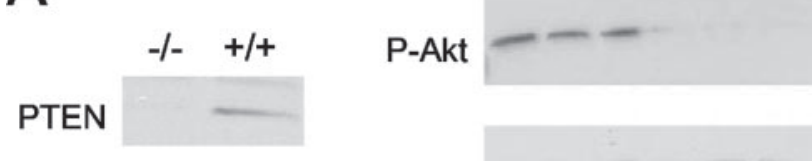

Total Akt

B
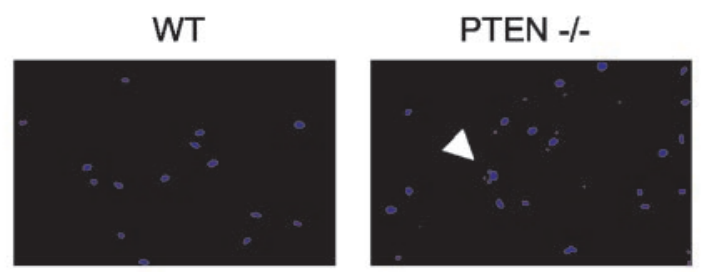

P-Akt
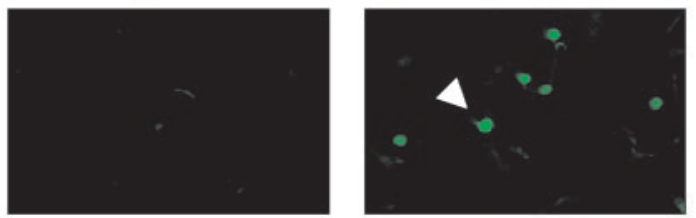

Merge
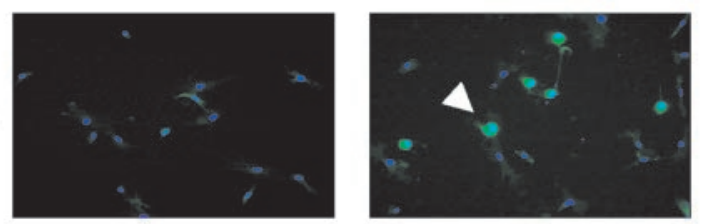

C

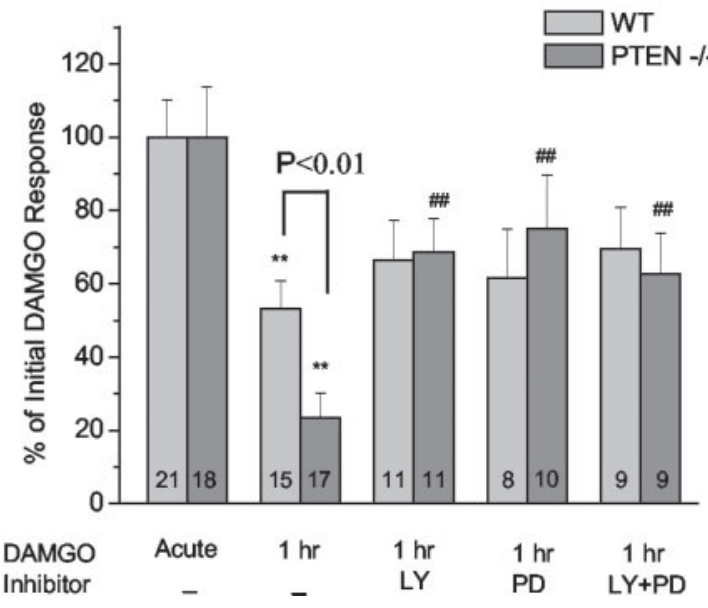

Figure 6. PTEN deletion leads to constitutive activation of the PI3-Akt pathway and acceleration of chronic DAMGO desensitization in DRG neurons. $A$, Immunoblotting analyses of PTEN, phospho-Akt (P-Akt), and total Akt in DRG lysates derived from PTEN - / - and wild-type $(+/+)$ mice. Each lane used the sample from a different animal. Note the loss of PTEN protein and marked increase in Akt phosphorylation in PTEN - / - DRG. B, Immunofluorescent images of DRG cultures stained for nuclear DAPI (blue) and P-Akt (green). Strong P-Akt staining was seen in PTEN - / - but not wild-type (WT) neurons in the absence of DAMGO. Magnification, $200 \times$. C, Chronic DAMG0 desensitization in PTEN - / - and wild-type DRG neurons. Acute DAMGO responses decayed much faster in the mutant neurons relative to wild types after a $1 \mathrm{hr}$ pretreatment. This enhanced desensitization was reversed to the wild-type level by $10 \mu \mathrm{m}$ LY294002 (LY) or PD98059 (PD) co-pretreatment. ${ }^{* *} p<0.01$ compared with the initial DAMG0 response in untreated neurons of the respective genotype. ${ }^{\#} p<0.01$ compared with cells pretreated with $1 \mathrm{hr}$ DAMG0 alone.

\section{Cross talk between the PI3K-Akt pathway and MAPK in regulating chronic desensitization}

The present study provides first evidence for an important role of Akt in opioid desensitization. Full activation of Akt re- quires its binding to PI3K lipid products and phosphorylation at Thr-308 and Ser-473 by phosphoinositide-dependent kinase- 1 in the presence of $\mathrm{PIP}_{3}$. Dephosphorylation of $\mathrm{PIP}_{3}$ by PTEN thus serves as a negative feedback control of PI3K-Akt signaling (Cantrell, 2001). PI3K inhibitors significantly attenuated chronic desensitization. PTEN deletion resulted in constitutive activation of Akt and enhanced desensitization in a PI3K-dependent manner. These data strongly suggest that the PI3K-Akt pathway is essential for $\mu$-opioid desensitization. Interestingly, blocking MAPK with PD98059 was equally as effective as PI3K inhibition in reducing desensitization. There was no additive effect when both kinases were inhibited, suggesting that they act in a common pathway. In many cell types, $\mathrm{G}_{\mathrm{i}}$-coupled receptors mediate MAPK activation through a $G \beta \gamma$-dependent pathway, which involves Shc phosphorylation, formation of the Shc-growth factor receptor-bound protein 2-Sos complex, and sequential activation of Ras, Raf, and MEK (van Biesen et al., 1995). PI3K activity is required in this pathway at a point upstream of Sos and Ras activation (Hawes et al., 1996). Studies in COS-7 and Chinese hamster ovary cells have shown that $\mu$ agonists activate MAPK through a $G \beta \gamma$ - and Ras-Raf-dependent mechanism (Belcheva et al., 1998) and that this effect is mediated in part via PI3K (Polakiewicz et al., 1998; Ai et al., 1999). DRG neurons may use a similar, G $\beta \gamma$ - and PI3K-dependent pathway to activate MAPK during opioid signaling.

The complexity of interactions between the PI3K-Akt pathway and MAPK was demonstrated by differential changes of Akt and MAPK in PTEN - / - neurons. Although both serve as downstream effectors of PI3K, PTEN deletion selectively upregulated Akt but not MAPK activity. This indicates that PI3K may use different signals to activate Akt and MAPK. In addition to its lipid kinase activity, PI3K possesses a serine-threonine kinase activity (Vanhaesebroeck and Waterfield, 1999). Although Akt activation depends on PI3K lipid products, stimulation of MAPK can be achieved solely through PI3K protein kinase activity (Bondeva et al., 1998). This could well explain why PTEN deletion, which increases cellular levels of $\mathrm{PIP}_{3}$ but not PI3K activity itself, failed to stimulate MAPK. Despite the lack of constitutive activation of MAPK, PD98059 nevertheless reversed PI3K-Akt-dependent acceleration of desensitization in PTEN-/- neurons. Therefore, after agonist stimulation, the MEK-MAPK pathway may provide positive feedback signals to enable full expression of PI3K-Akt activity in mutant neurons. Such a cross talk, although not shown previously in neurons, has been demonstrated in multiple cell lines in which Ser-473 phosphorylation by MEK-p38 MAPK is required for full activation of Akt (Baudhuin et al., 2002).

In summary, PI3K-Akt and MEK-MAPK pathways may interact at different levels, providing an integrated control over opioid signaling and desensitization. Although the loci of their actions may be multiple, our data provide novel evidence for postreceptor regulation that prevents effective G-protein-Ca ${ }^{2+}$ channel interactions. These findings may be highly relevant to understanding the mechanisms for opioid tolerance and the regulation of GPCR signaling in general.

\section{References}

Ai W, Gong J, Yu L (1999) MAP kinase activation by mu opioid receptor involves phosphatidylinositol 3-kinase but not the cAMP-PKA pathway. FEBS Lett 456:196-200.

Alessi DR, Cuenda A, Cohen P, Dudley DT, Saltiel AR (1995) PD 098059 is a specific inhibitor of the activation of mitogen-activated protein kinase kinase in vitro and in vivo. J Biol Chem 270:27489-27494.

Alvarez VA, Arttamangkul S, Dang V, Salem A, Whistler JL, Von Zastrow M, 
Grandy DK, Williams JT (2002) $\mu$-Opioid receptors: ligand-dependent activation of potassium conductance, desensitization, and internalization. J Neurosci 22:5769-5776.

Baudhuin LM, Cristina KL, Lu J, Xu Y (2002) Akt activation induced by lysophosphatidic acid and sphingosine-1-phosphate requires both mitogen-activated protein kinase kinase and p38 mitogen-activated protein kinase and is cell-line specific. Mol Pharmacol 62:660-671.

Beland B, Fitzgerald M (2001) Mu- and delta-opioid receptors are downregulated in the largest diameter primary sensory neurons during postnatal development in rats. Pain 90:143-150.

Belcheva MM, Vogel Z, Ignatova E, Avidor-Reiss T, Zippel R, Levy R, Young EC, Barg J, Coscia CJ (1998) Opioid modulation of extracellular signalregulated protein kinase activity is ras-dependent and involves Gbetagamma subunits. J Neurochem 70:635-645.

Blanchet C, Luscher C (2002) Desensitization of mu-opioid receptorevoked potassium currents: initiation at the receptor, expression at the effector. Proc Natl Acad Sci USA 99:4674-4679.

Bondeva T, Pirola L, Bulgarelli-Leva G, Rubio I, Wetzker R, Wymann MP (1998) Bifurcation of lipid and protein kinase signals of PI3Kgamma to the protein kinases PKB and MAPK. Science 282:293-296.

Borgland SL, Connor M, Osborne PB, Furness JB, Christie MJ (2003) Opioid agonists have different efficacy profiles for G-protein activation, rapid desensitization, and endocytosis of mu-opioid receptors. J Biol Chem 278:18776-18784.

Bourinet E, Soong TW, Stea A, Snutch TP (1996) Determinants of the G-protein-dependent opioid modulation of neuronal calcium channels. Proc Natl Acad Sci USA 93:1486-1491.

Cantrell DA (2001) Phosphoinositide 3-kinase signalling pathways. J Cell Sci 114:1439-1445.

Chuang TT, Iacovelli L, Sallese M, De Blasi A (1996) G-protein-coupled receptors: heterologous regulation of homologous desensitization and its implications. Trends Pharmacol Sci 17:416-421.

Claing A, Laporte SA, Caron MG, Lefkowitz RJ (2002) Endocytosis of G-protein-coupled receptors: roles of G-protein-coupled receptor kinases and beta-arrestin proteins. Prog Neurobiol 66:61-79.

Dascal N (2001) Ion-channel regulation by G-proteins. Trends Endocrinol Metab 12:391-398.

Davare MA, Avdonin V, Hall DD, Peden EM, Burette A, Weinberg RJ, Horne MC, Hoshi T, Hell JW (2001) A beta2 adrenergic receptor signaling complex assembled with the Ca2 + channel Cav1.2. Science 293:98-101.

De Waard M, Liu H, Walker D, Scott VE, Gurnett CA, Campbell KP (1997) Direct binding of G-protein betagamma complex to voltage-dependent calcium channels. Nature 385:446-450.

Diverse-Pierluissi M, Goldsmith PK, Dunlap K (1995) Transmittermediated inhibition of N-type calcium channels in sensory neurons involves multiple GTP-binding proteins and subunits. Neuron 14:191-200.

Diverse-Pierluissi MA, Fischer T, Jordan JD, Schiff M, Ortiz DF, Farquhar MG, De Vries L (1999) Regulators of G-protein signaling proteins as determinants of the rate of desensitization of presynaptic calcium channels. J Biol Chem 274:14490-14494.

Dohlman HG, Thorner J (1997) RGS proteins and signaling by heterotrimeric G-proteins. J Biol Chem 272:3871-3874.

Fields TA, Casey PJ (1995) Phosphorylation of Gz alpha by protein kinase C blocks interaction with the beta gamma complex. J Biol Chem 270:23119-22125.

Fitzgerald EM (2000) Regulation of voltage-dependent calcium channels in rat sensory neurones involves a Ras-mitogen-activated protein kinase pathway. J Physiol (Lond) 527:433-444.

Garcia-Caballero A, Olivares-Reyes JA, Catt KJ, Garcia-Sainz JA (2001) Angiotensin AT(1) receptor phosphorylation and desensitization in a hepatic cell line. Roles of protein kinase $\mathrm{c}$ and phosphoinositide 3-kinase. Mol Pharmacol 59:576-585.

Garrison TR, Zhang Y, Pausch M, Apanovitch D, Aebersold R, Dohlman HG (1999) Feedback phosphorylation of an RGS protein by MAP kinase in yeast. J Biol Chem 274:36387-36391.

Groszer M, Erickson R, Scripture-Adams DD, Lesche R, Trumpp A, Zack JA, Kornblum HI, Liu X, Wu H (2001) Negative regulation of neural stem/ progenitor cell proliferation by the Pten tumor suppressor gene in vivo. Science 294:2186-2189.

Hamid J, Nelson D, Spaetgens R, Dubel SJ, Snutch TP, Zamponi GW (1999) Identification of an integration center for cross talk between protein ki- nase C and G-protein modulation of N-type calcium channels. J Biol Chem 274:6195-6202.

Hawes BE, Luttrell LM, van Biesen T, Lefkowitz RJ (1996) Phosphatidylinositol 3-kinase is an early intermediate in the G beta gamma-mediated mitogen-activated protein kinase signaling pathway. J Biol Chem 271:12133-12136.

Hawes BE, Fried S, Yao X, Weig B, Graziano MP (1998) Nociceptin (ORL-1) and mu-opioid receptors mediate mitogen-activated protein kinase activation in $\mathrm{CHO}$ cells through a Gi-coupled signaling pathway: evidence for distinct mechanisms of agonist-mediated desensitization. J Neurochem 71:1024-1033.

Herlitze S, Garcia DE, Mackie K, Hille B, Scheuer T, Catterall WA (1996) Modulation of $\mathrm{Ca} 2+$ channels by G-protein beta gamma subunits. Nature 380:258-262.

Ikeda SR (1996) Voltage-dependent modulation of N-type calcium channels by G-protein beta gamma subunits. Nature 380:255-258.

Kajikawa Y, Saitoh N, Takahashi T (2001) GTP-binding protein beta gamma subunits mediate presynaptic calcium current inhibition by GABA(B) receptor. Proc Natl Acad Sci USA 98:8054-8058.

Kaneko S, Yada N, Fukuda K, Kikuwaka M, Akaike A, Satoh M (1997) Inhibition of $\mathrm{Ca} 2+$ channel current by mu- and kappa-opioid receptors coexpressed in Xenopus oocytes: desensitization dependence on Ca2+ channel alpha 1 subunits. Br J Pharmacol 121:806-812.

King AP, Hall KE, Macdonald RL (1999) kappa- and mu-Opioid inhibition of N-type calcium currents is attenuated by 4 beta-phorbol 12-myristate 13 -acetate and protein kinase $\mathrm{C}$ in rat dorsal root ganglion neurons. J Pharmacol Exp Ther 289:312-320.

Kovoor A, Henry D, Chavkin C (1995) Agonist-induced desensitization of the mu opioid receptor-coupled potassium channel (GIRK1). J Biol Chem 270:589-595.

Law PY, Wong YH, Loh HH (2000) Molecular mechanisms and regulation of opioid receptor signaling. Annu Rev Pharmacol Toxicol 40:389-430.

Lei S, Dryden WF, Smith PA (1998) Involvement of Ras/MAP kinase in the regulation of $\mathrm{Ca} 2+$ channels in adult bullfrog sympathetic neurons by nerve growth factor. J Neurophysiol 80:1352-1361.

Lin FT, Miller WE, Luttrell LM, Lefkowitz RJ (1999) Feedback regulation of beta-arrestin1 function by extracellular signal-regulated kinases. J Biol Chem 274:15971-15974.

Lopez-Ilasaca M (1998) Signaling from G-protein-coupled receptors to mitogen-activated protein (MAP)-kinase cascades. Biochem Pharmacol 56:269-277.

Luebke JI, Dunlap K (1994) Sensory neuron N-type calcium currents are inhibited by both voltage-dependent and -independent mechanisms. Pflügers Arch 428:499-507.

Mark MD, Wittemann S, Herlitze S (2000) G-protein modulation of recombinant P/Q-type calcium channels by regulators of G-protein signalling proteins. J Physiol (Lond) 528:65-77.

Morikawa H, Fukuda K, Mima H, Shoda T, Kato S, Mori K (1998) Desensitization and resensitization of delta-opioid receptor-mediated Ca2+ channel inhibition in NG108-15 cells. Br J Pharmacol 123:1111-1118.

Murthy KS, Grider JR, Makhlouf GM (2000) Heterologous desensitization of response mediated by selective PKC-dependent phosphorylation of G(i-1) and G(i-2). Am J Physiol Cell Physiol 279:C925-C934.

Nomura K, Reuveny E, Narahashi T (1994) Opioid inhibition and desensitization of calcium channel currents in rat dorsal root ganglion neurons. J Pharmacol Exp Ther 270:466-474.

Parri HR, Lansman JB (1996) Multiple components of $\mathrm{Ca}^{2+}$ channel facilitation in cerebellar granule cells: expression of facilitation during development in culture. J Neurosci 16:4890-4902.

Polakiewicz RD, Schieferl SM, Dorner LF, Kansra V, Comb MJ (1998) A mitogen-activated protein kinase pathway is required for mu-opioid receptor desensitization. J Biol Chem 273:12402-12406.

Rusin KI, Moises HC (1995) $\mu$-Opioid receptor activation reduces multiple components of high-threshold calcium current in rat sensory neurons. J Neurosci 15:4315-4327.

Samoriski GM, Gross RA (2000) Functional compartmentalization of opioid desensitization in primary sensory neurons. J Pharmacol Exp Ther 294:500-509.

Schmidt H, Schulz S, Klutzny M, Koch T, Handel M, Hollt V (2000) Involvement of mitogen-activated protein kinase in agonist-induced phosphorylation of the mu-opioid receptor in HEK 293 cells. J Neurochem 74:414-422. 
Schroeder JE, McCleskey EW (1993) Inhibition of $\mathrm{Ca}^{2+}$ currents by a $\mu$-opioid in a defined subset of rat sensory neurons. J Neurosci 13:867-873.

Sun H, Lesche R, Li DM, Liliental J, Zhang H, Gao J, Gavrilova N, Mueller B, Liu $\mathrm{X}, \mathrm{Wu} \mathrm{H}$ (1999) PTEN modulates cell cycle progression and cellsurvival by regulating phosphatidylinositol 3,4,5,-trisphosphate and Akt/protein kinase B signaling pathway. Proc Natl Acad Sci USA 96:6199-6204.

Toker A (2000) Protein kinases as mediators of phosphoinositide 3-kinase signaling. Mol Pharmacol 57:652-658.

Toth PT, Shekter LR, Ma GH, Philipson LH, Miller RJ (1996) Selective G-protein regulation of neuronal calcium channels. J Neurosci 16:4617-4624.

Ui M, Okada T, Hazeki K, Hazeki O (1995) Wortmannin as a unique probe for an intracellular signalling protein, phosphoinositide 3-kinase. Trends Biochem Sci 20:303-307. van Biesen T, Hawes BE, Luttrell DK, Krueger KM, Touhara K, Porfiri E, Sakaue M, Luttrell LM, Lefkowitz RJ (1995) Receptor-tyrosine-kinaseand G beta gamma-mediated MAP kinase activation by a common signalling pathway. Nature 376:781-784.

Vanhaesebroeck B, Waterfield MD (1999) Signaling by distinct classes of phosphoinositide 3-kinases. Exp Cell Res 253:239-254.

Vlahos CJ, Matter WF, Hui KY, Brown RF (1994) A specific inhibitor of phosphatidylinositol 3-kinase, 2-(4-morpholinyl)-8-phenyl-4H-1-benzopyran4-one (LY294002). J Biol Chem 269:5241-5248.

Womack MD, McCleskey EW (1995) Interaction of opioids and membrane potential to modulate $\mathrm{Ca} 2+$ channels in rat dorsal root ganglion neurons. J Neurophysiol 73:1793-1798.

Zamponi GW, Bourinet E, Nelson D, Nargeot J, Snutch TP (1997) Crosstalk between G-proteins and protein kinase C mediated by the calcium channel alpha1 subunit. Nature 385:442-446. 